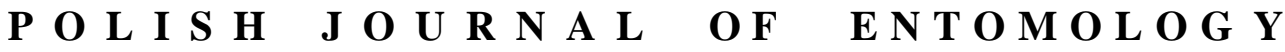

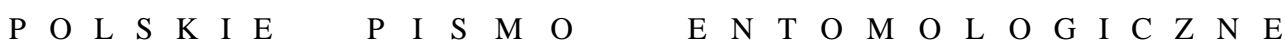

VOL. 83: 79-97

Lublin

31 March 2014

DOI: $10.2478 /$ pjen-2014-0006

\section{Potential of an insect growth regulator in the management of the rice moth Corcyra cephalonica STAInTon, 1866 (Lepidoptera: Pyralidae)}

\author{
PRIYANKA TRIPATHI, S.K. TIWARI
}

Department of Zoology, D.D.U. Gorakhpur University, Gorakhpur- 273009, U.P. (India), email: sktzddu@rediffmail.com

\begin{abstract}
The present investigation reveals the influence of methoprene, an IGR, on the ontogeny, growth duration and adult longevity of the rice moth Corcyra cephalonica. Twenty-five larvae of different instars $\left(1^{\text {st }}, 2^{\text {nd }}, 3^{\text {rd }}\right.$ and $\left.4^{\text {th }}\right)$ of $C$. cephalonica were exposed to the juvenile hormone analogue methoprene in order to evaluate its potential effect on larval mortality, pupation, pupal mortality, adult emergence, growth duration and adult longevity. These different instars larvae were treated with 2, 4, 8 and $12 \mathrm{ppm}$ of methoprene in an artificial diet (coarsely ground jowar mixed with $5 \%$ yeast powder) where the control received acetone alone. The results reveal significant differences in all the parameters mentioned above as compared to the control.
\end{abstract}

KEY WORDS: methoprene, growth duration, pupation, adult emergence, longevity.

\section{INTRODUCTION}

Stored cereal pest management is still a puzzling problem of the world. The presence of insects in stored food directly affects both the quantity and quality of the commodity (Wilbur \& Mills 1985, Hill 1990, BURKHOLDER \& FAUSTINI 1991). This is caused not only by feeding, but also by the heat produced by the respiratory and metabolic functions of the insects. Accumulation of frass (exuviae, egg shells, dead insects, pupal cases, faecal matter) (MONDAL 1983, 1984, 1994, KHAN \& MANNAN 1991) and webbing of food (HILL 1990) are of great nuisance. Insect infestation in stored food causes major health hazards. Moreover, the quinones secreted by some of pests, particularly tenebrionid beetles (ROTH 1943, MONDAL 1985, 1992) are acutely toxic, allergenic and carcinogenic to human beings 


\section{(LADISCH et al. 1967).}

The rice moth Corcyra cephalonica STAINTON, 1866 is a notorious lepidopteran pest of stored cereals and cereal products in tropical and sub-tropical regions of the world (AYYAR 1920, MUNRO \& THOMSON 1929). Its larval stages cause serious damage to rice, gram, sorghum, maize, ground nut, cotton seeds, peanuts, linseeds, raisins, nutmeg, chocolate, army biscuits, wheat, coffee, cocoa beans and milled products (ATwAL 1976, PILTZ 1977, ALLOTEY \& KUMAR 1985, ALLOTEY 1991).

Concern about the impact of pesticides on health, non-target organisms and the environment has resulted in the search for alternative control measures for stored-product insect pests. Amongst such "alternatives" are insect growth regulators (IGRs), a class of biorational compounds that disrupt the normal development of insects. IGRs have been developed commercially and are being used to control insect pests in agriculture, forestry, public health and stored products. IGRs affect the biology of the treated insects, for example, their embryonic and post-embryonic development, reproduction, behaviour and mortality. Abnormal morphogenesis is the observed effect of the action of IGRs on insects. Many of them are more potent than current insecticides, even against the eggs. Compared with conventional insecticides, IGRs do not exhibit quick knock-down effects on insects or cause mortality, but long-term exposure to these compounds largely stops population growth, as a result of the above-mentioned effects in both parents and progeny. The first use of IGRs against stored-product pests was reported by THOMAS \& BHATNAGAR-THOMAS (1968), but they were only tested on a small number of insect species. Ordinarily, control measures in stores are based on fumigation with chemicals like hydrogen phosphate. Residues and insect resistance are reasons for potentially limiting the use of fumigation with chemicals in the near future (WMO 1994). IGRs are selective for insects and have low mammalian toxicity, and are usually considered to be "reduced-risk insecticides". With the increasing emphasis on using chemicals that pose less risk, have low mammalian toxicity and are specific to insects, there is renewed interest in using IGRs in pest management systems for stored grain (OBERLANDER et al. 1997).

The term IGR was coined by STALL (1975) to describe a class of bio-rational compounds. Through greater selectivity of action, these compounds appear to fit the requirements for "Third Generation Pesticides" (WILLIAMs 1967) that disrupt the normal development of several species of insects (HENRICK et al. 1973). On the basis of the mode of action, workers (WILlis 1974, StAAL 1975, MARX 1977, BENGSTON 1987, REYNOLDS 1987, WING \& ALLER 1990) grouped IGRs into three categories: (i) juvenile hormones (JHs) and their analogues (JHAs), also known as juvenoids, (ii) ecdysone agonists and (iii) chitin synthesis inhibitors (CSIs) or moult inhibitors (MIs). Physiological and behavioural processes in insects are controlled by the juvenile hormones, ecdysones and moulting hormones; the first two groups of compounds regulate morphogenetic changes during 
metamorphosis (WILLIS 1974).

Methoprene is a long-chain hydrocarbon ester active as an insect growth regulator. An analogue of juvenile hormone, it affects the egg and larval stages of stored-product insects. It is a terpenoid and is considered to have higher potency and better field stability than naturally occurring juvenile hormone. It is effective against a number of stored-product insect pests. In the United States, methoprene was re-introduced into the stored-product market in 2002 by Wellmark International and marketed as the commercial formulation Dicon II.

In the present investigation, an attempt has been made to study the behaviour of the rice moth, a stored cereal pest, following treatment with methoprene. The behavioural studies examine the effect of methoprene on this insect's ontogeny, growth duration and longevity. The results obtained, in turn, would be of great importance in framing guidelines for interrupting the life-cycle of this pest by manipulating its metabolic framework. This technical contribution will provide an important and meaningful message to entomologists working on insect growth regulators, who desire to apply this knowledge skilfully to control infestation on stored products in godowns and other storage areas by this notorious insect Corcyra cephalonica. Therefore, the present study will take the field of hormonal analogues a step forward, and its results will be of immense importance from both the academic as well as the economic points of view.

\section{Acknowledgements}

The authors thank Prof. V.B. UpadhaYAY, Head, Department of Zoology, D.D.U. Gorakhpur University, Gorakhpur, for providing laboratory facilities and $\mathrm{M} / \mathrm{s}$ AccuStandard, New Haven, CT 06513, USA for providing the methoprene (P-157N, Lot 18828).

\section{MATERIALS AND METHODS}

\section{Maintenance of laboratory stock culture}

Corcyra cephalonica adults were obtained from the laboratory-maintained stock culture on a normal dietary medium composed of coarsely ground jowar Sorghum bicolor (L.) MoENCH, 1794, mixed with 5\% (w/w) powdered yeast in large glass containers $(150 \mathrm{~mm}$ diameter, $200 \mathrm{~mm}$ height) at temperature $26 \pm 1{ }^{\circ} \mathrm{C}$, relative humidity (RH) $93 \pm 5 \%$ and a light regime of $12 \mathrm{hrs} \mathrm{light}$ and $12 \mathrm{hrs}$ darkness. Such a standard culture was maintained throughout the year.

Methoprene (1-methylethyl (E,E)-11- methoxy-3,7,11-trimethyl- 2,4-dodecadienoate), a terpenoid juvenile hormone analogue, (P-157N, Lot 18828), was obtained from M/s AccuStandard, New Haven, CT06513, USA. 


\section{Preparation of different concentrations of methoprene in dietary media}

To prepare the different concentrations of methoprene in dietary media, a stock solution of known concentration of methoprene was prepared in the requisite organic solvent (acetone) and adjusted via serial dilutions with acetone to achieve the desired concentrations. Then the appropriate volumes of different concentrations of methoprene were thoroughly mixed with the required quantity of normal food (roughly ground jowar mixed with $5 \%(\mathrm{w} / \mathrm{w})$ yeast powder) to obtain the different concentrations of methoprene. This treated food was then air dried at room temperature to eliminate excess acetone. For control purposes, the normal food was thoroughly mixed with a suitable volume of acetone similar to that of the treated food and then air dried in the same way.

Evaluation of the toxicity of methoprene towards the developmental stages of Corcyra cephalonica

To investigate the toxic effects of various concentrations of methoprene, freshly hatched larvae of Corcyra cephalonica were allowed to feed on a normal dietary medium (kept in $250 \mathrm{ml}$ beakers) for exactly 4 days. On the $5^{\text {th }}, 10^{\text {th }}, 15^{\text {th }}$ and $20^{\text {th }}$ days, twenty-five larvae of the $1^{\text {st }}, 2^{\text {nd }}, 3^{\text {rd }}$ and $4^{\text {th }}$ instars respectively were transferred to similar rearing chambers containing $50 \mathrm{gm}$ of dietary medium mixed and treated separately with different known concentrations of methoprene. The experiment was conducted on 4 different concentrations, i.e. 2, 4, 8 and $12 \mathrm{ppm}$ of methoprene. Twenty-five larvae were also kept on a normal dietary medium as the control. On completion of the developmental cycle, the percentages of larval mortality, pupation, pupal mortality and adult emergence, as well as growth duration and longevity of adults were recorded.

\section{Growth duration, longevity, percentage pupation and adult emergence}

After emergence of the moth, the percentage pupation (number of pupae) and adult emergence (number of adults emerged) were recorded. On that basis the percentages of larval and pupal mortality were calculated. The growth duration (the time elapsing between egg laying and adult emergence) and longevity (lifespan) of emerged males and females of Corcyra cephalonica were recorded separately for all four experimental sets from the $1^{\text {st }}$, $2^{\text {nd }}, 3^{\text {rd }}$ and $4^{\text {th }}$ instar larvae exposed to various concentrations of methoprene and for the control.

The experiment was replicated six times and the data obtained were analysed statistically. Student's t-test was applied to determine the significant differences between the corresponding treated groups and the control $(\mathrm{p}<0.1$ to $\mathrm{p}<0.001)$ using GraphPad, QuickCalcs Software. 


\section{RESULTS}

\section{Effect of methoprene on larval mortality}

Mortality in larvae of different instars of Corcyra cephalonica rose with increasing concentrations of methoprene. The respective percentage mortality in $1^{\text {st }}$ instar larvae was $14.67 \pm 2.07,18.00 \pm 2.19,20.00 \pm 2.53$ and $26.67 \pm 3.26$ when treated with $2,4,8$ and 12 ppm of methoprene, whereas in the control it was $3.33 \pm 3.01 \%$ (Table 1). The results for $2^{\text {nd }}, 3^{\text {rd }}$ and $4^{\text {th }}$ instar larvae were similar to each other. Larval mortality was higher in $1^{\text {st }}$ instar larvae than in any of the $2^{\text {nd }}, 3^{\text {rd }}$ and $4^{\text {th }}$ instar larvae.

Table 1. Effect of methoprene on the percentage of larval mortality of different larval instars of $C$. cephalonica at temperature $26^{\circ} \pm 1^{\circ} \mathrm{C}$, relative humidity (r. h.) $93 \pm 5 \%$ and a light regime of $12 \mathrm{~h}$ light and $12 \mathrm{~h}$ darkness.

\begin{tabular}{|c|c|c|c|c|}
\hline \multirow{2}{*}{$\begin{array}{c}\text { Methoprene } \\
\text { concentration [ppm] }\end{array}$} & \multicolumn{4}{|c|}{ Percentage Larval Mortality } \\
\hline & $1^{\text {st }}$ instar $^{\#}$ & $2^{\text {nd }}$ instar $^{\#}$ & $3^{\text {rd }}$ instar $^{\#}$ & $4^{\text {th }}$ instar $^{\#}$ \\
\hline 0 & $3.33 \pm 3.01$ & $3.33 \pm 3.01$ & $3.33 \pm 3.01$ & $3.33 \pm 3.01$ \\
\hline 2 & $14.67 \pm 2.07^{\mathrm{ac}}$ & $13.33 \pm 2.07^{\mathrm{ab}}$ & $10.00 \pm 2.19^{\mathrm{bc}}$ & $5.33 \pm 2.07^{\mathrm{c}^{\prime}}$ \\
\hline 4 & $18.00 \pm 2.19^{\mathrm{a}}$ & $18.00 \pm 2.19^{\mathrm{ac}^{\prime}}$ & $14.00 \pm 2.19^{\mathrm{ab}^{\prime}}$ & $9.33 \pm 3.27^{\mathrm{cc}^{\prime}}$ \\
\hline 8 & $20.00 \pm 2.53^{\mathrm{ab}}$ & $21.33 \pm 2.07^{\mathrm{ab}^{\prime}}$ & $18.67 \pm 2.07^{\mathrm{ac}^{\prime}}$ & $14.00 \pm 2.19^{\mathrm{ab}}$ \\
\hline 12 & $26.67 \pm 3.26^{\mathrm{a}}$ & $25.33 \pm 2.07^{\mathrm{a}}$ & $22.00 \pm 2.19^{\mathrm{a}}$ & $19.33 \pm 3.01^{\mathrm{a}}$ \\
\hline
\end{tabular}

\# - Values expressed as the mean \pm SD of six replicates.

${ }^{\mathrm{a}}{ }^{\mathrm{b}}$ and $^{\mathrm{c}}-$ Values were significantly different ( $\mathrm{p}<0.001, \mathrm{p}<0.01$ and $\mathrm{p}<0.05$ respectively) from the control when the t-test was applied.

$\mathrm{b}^{\prime}$ and ${ }^{\mathrm{c}}$ - Values were significantly different $(\mathrm{p}<0.01$ and $<0.05$ respectively) within the various concentrations when the t-test was applied.

\section{Effect of methoprene on pupation}

With increasing methoprene concentration, a significant reduction in percentage pupation occurred. When $1^{\text {st }}$ instar larvae were treated with methoprene at different concentrations, i.e. $2,4,8$ and $12 \mathrm{ppm}$, percentage pupation was $85.33 \pm 2.07,82.00 \pm 2.19$, $80.00 \pm 2.19$ and $73.33 \pm 3.27$ respectively, while in the control it was $96.67 \pm 3.01 \%$ (Table 2). Younger instars $\left(1^{\text {st }}\right.$ and $\left.2^{\text {nd }}\right)$ were more affected than older instars $\left(3^{\text {rd }}\right.$ and $\left.4^{\text {th }}\right)$. When $1^{\text {st }}, 2^{\text {nd }}, 3^{\text {rd }}$ and $4^{\text {th }}$ instars were treated with $12 \mathrm{ppm}$ of methoprene, the respective percentage pupation was $73.33 \pm 3.27,74.67 \pm 2.07,78.00 \pm 2.19$ and $80.67 \pm 3.01$. This result shows that at higher larval stages there is a smaller reduction in pupation. 
Table 2. Effect of methoprene on the percentage pupation of different larval instars of C. cephalonica at temperature $26^{\circ} \pm 1^{\circ} \mathrm{C}$, relative humidity (r. h.) $93 \pm 5 \%$ and a light regime of $12 \mathrm{~h}$ light and $12 \mathrm{~h}$ darkness.

\begin{tabular}{|c|c|c|c|c|}
\hline \multirow{2}{*}{$\begin{array}{c}\text { Methoprene } \\
\text { concentration [ppm] }\end{array}$} & \multicolumn{4}{|c|}{ Percentage Pupation $^{\text {rd }}$} \\
\cline { 2 - 5 } & $\mathbf{1}^{\text {st }}$ instar $^{\#}$ & $\mathbf{2}^{\text {nd }}$ instar $^{\#}$ & $\mathbf{3}^{\text {rd }}$ instar $^{\#}$ & $\mathbf{4}^{\text {th }}$ instar $^{\#}$ \\
\hline 0 & $96.67 \pm 3.01$ & $96.67 \pm 3.01$ & $96.67 \pm 3.01$ & $96.67 \pm 3.01$ \\
\hline 2 & $85.33 \pm 2.07^{\mathrm{ac}}$ & $86.67 \pm 2.07^{\mathrm{ab}}$ & $90.00 \pm 2.19^{\mathrm{bc}^{\prime}}$ & $94.67 \pm 2.07^{\mathrm{c}^{\prime}}$ \\
\hline 4 & $82.00 \pm 2.19^{\mathrm{a}}$ & $82.00 \pm 2.19^{\mathrm{ac}}$ & $86.00 \pm 2.19^{\mathrm{ab}^{\mathrm{a}}}$ & $90.67 \pm 3.27^{\mathrm{bc}^{\mathrm{a}}}$ \\
\hline 8 & $80.00 \pm 2.53^{\mathrm{ab}}$ & $78.67 \pm 2.07^{\mathrm{ab}}$ & $81.33 \pm 2.07^{\mathrm{ac}^{\prime}}$ & $86.00 \pm 2.19^{\mathrm{ab}^{\prime}}$ \\
\hline 12 & $73.33 \pm 3.27^{\mathrm{a}}$ & $74.67 \pm 2.07^{\mathrm{a}}$ & $78.00 \pm 2.19^{\mathrm{a}}$ & $80.67 \pm 3.01^{\mathrm{a}}$ \\
\hline
\end{tabular}

\# - Values expressed as the mean \pm SD of six replicates.

${ }^{a}$ and ${ }^{b}-$ Values were significantly different $(\mathrm{p}<0.001$ and $\mathrm{p}<0.01$ respectively) from the control when the t-test was applied.

b' and ' ${ }^{\prime}-$ Values were significantly different $(\mathrm{p}<0.01$ and $<0.05$ respectively) within the various concentrations when the t-test was applied.

\section{Effect of methoprene on pupal mortality}

Pupal mortality becomes significantly greater with increasing methoprene concentration. It was $7.03 \pm 2.57 \%$ in $1^{\text {st }}$ instar larvae treated with $2 \mathrm{ppm}$ of methoprene and increased to $29.10 \pm 2.88 \%$ with $12 \mathrm{ppm}$ (Table 3 ). The findings were similar in the case of $2^{\text {nd }}, 3^{\text {rd }}$ and $4^{\text {th }}$ instar larvae. There was no pupal mortality in the control dietary media, or in the case of $2^{\text {nd }}$ instar larvae at $2 \mathrm{ppm}$ and in $3^{\text {rd }}$ and $4^{\text {th }}$ instar larvae at 2 and $4 \mathrm{ppm}$ of methoprene. The results show that pupal mortality in younger instars was much more pronounced in comparison to the control.

Table 3. Effect of methoprene on the percentage of pupal mortality of different larval instars of $C$. cephalonica at temperature $26^{\circ} \pm 1^{\circ} \mathrm{C}$ and relative humidity (r. h.) $93 \pm 5 \%$ and a light regime of $12 \mathrm{~h}$ light and $12 \mathrm{~h}$ darkness.

\begin{tabular}{|c|c|c|c|c|}
\hline \multirow{2}{*}{$\begin{array}{c}\text { Methoprene } \\
\text { concentration [ppm] }\end{array}$} & \multicolumn{4}{|c|}{ Percentage Pupal Mortality } \\
\hline & $1^{\text {st }}$ instar $^{\#}$ & $2^{\text {nd }}$ instar $^{\#}$ & $3^{\text {rd }}$ instar $^{\#}$ & $4^{\text {th }}$ instar $^{\#}$ \\
\hline 0 & 00 & 00 & 00 & 00 \\
\hline 2 & $7.03 \pm 2.57^{\mathrm{ac}}$ & $00^{\mathrm{aa}^{\prime}}$ & 00 & 00 \\
\hline 4 & $11.43 \pm 2.77^{\mathrm{aa}}$ & $6.55 \pm 2.68^{\mathrm{ab}}$ & $00^{\mathrm{aa}^{\prime}}$ & $00^{\mathrm{aa}^{\prime}}$ \\
\hline 8 & $21.60 \pm 2.21^{\mathrm{aa}^{\prime}}$ & $11.90 \pm 2.74^{\mathrm{ab}^{\mathrm{b}}}$ & $10.70 \pm 3.86^{\mathrm{ab}}$ & $6.20 \pm 2.41^{\mathrm{ab}}$ \\
\hline 12 & $29.10 \pm 2.88^{\mathrm{a}}$ & $17.80 \pm 2.52^{\mathrm{a}}$ & $18.90 \pm 3.02^{\mathrm{a}}$ & $12.40 \pm 2.89^{\circ}$ \\
\hline
\end{tabular}

\# - Values expressed as the mean $\pm \mathrm{SD}$ of six replicates.

a - Values were significantly different $(\mathrm{p}<0.001)$ from the control when the t-test was applied.

$\mathrm{a}^{\prime}, \mathrm{b}^{\prime}$ and ${ }^{\mathrm{c}^{\prime}}-$ Values were significantly different $(\mathrm{p}<0.001, \mathrm{p}<0.01$ and $<0.05$ respectively) within the various concentrations when the t-test was applied. 


\section{Effect of methoprene on adult emergence}

As the methoprene concentration increased, the percentage of adult emergence decreased (Table 4). There was a significant difference was found between treatments of $1^{\text {st }}, 2^{\text {nd }}, 3^{\text {rd }}$ and $4^{\text {th }}$ instar larvae and the control (Table 4$)$. When $1^{\text {st }}$ instar larvae were treated with a concentration of $12 \mathrm{ppm}$ the lowest adult emergence, i.e. $52.00 \pm 3.58 \%$, was observed in comparison to the control, i.e. $96.67 \pm 3.01 \%$. The percentage adult emergence of $1^{\text {st }}, 2^{\text {nd }}, 3^{\text {rd }}$, and $4^{\text {th }}$ instars larvae treated with $12 \mathrm{ppm}$ of methoprene was $52.00 \pm 3.58$, $61.33 \pm 2.07,63.33 \pm 3.93$ and $70.67 \pm 4.13$ respectively. This shows that younger instars $\left(1^{\text {st }}\right.$ and $\left.2^{\text {nd }}\right)$ were more affected than older ones $\left(3^{\text {rd }}\right.$ and $\left.4^{\text {th }}\right)$.

Table 4. Effect of methoprene on the percentage of adult emergence of different larval instars of C. cephalonica at temperature $26^{\circ} \pm 1{ }^{\circ} \mathrm{C}$, relative humidity (r. h.) $93 \pm 5 \%$ and a light regime of $12 \mathrm{~h}$ light and $12 \mathrm{~h}$ darkness.

\begin{tabular}{|c|c|c|c|c|}
\hline \multirow{2}{*}{$\begin{array}{c}\text { Methoprene } \\
\text { concentration [ppm] }\end{array}$} & \multicolumn{4}{|c|}{ Percentage Adult Emergence } \\
\hline & $1^{\text {st }}$ instar $^{\#}$ & $2^{\text {nd }}$ instar $^{\#}$ & $3^{\text {rd }}$ instar $^{\#}$ & $4^{\text {th }}$ instar $^{\#}$ \\
\hline 0 & $96.67 \pm 3.01$ & $96.67 \pm 3.01$ & $96.67 \pm 3.01$ & $96.67 \pm 3.01$ \\
\hline 2 & $79.33 \pm 3.01^{\text {aa }}$ & $86.67 \pm 2.07^{\mathrm{aa}}$ & $90.00 \pm 2.19^{\mathrm{bc}}$ & $94.67 \pm 2.07^{\mathrm{c}^{\mathrm{c}}}$ \\
\hline 4 & $72.67 \pm 3.93^{\text {aa }^{\prime}}$ & $76.67 \pm 3.93^{\text {aa' }}$ & $86.00 \pm 2.19^{\text {aa' }}$ & $90.67 \pm 3.27^{\text {ba }}$ \\
\hline 8 & $62.67 \pm 2.07^{\text {aa' }}$ & $69.33 \pm 3.27^{\mathrm{aa}^{\prime}}$ & $72.67 \pm 4.68^{\mathrm{ab}}$ & $80.67 \pm 3.01^{\mathrm{ab}}$ \\
\hline 12 & $52.00 \pm 3.58^{\mathrm{a}}$ & $61.33 \pm 2.07^{\mathrm{a}}$ & $63.33 \pm 3.93^{\mathrm{a}}$ & $70.67 \pm 4.13^{2}$ \\
\hline
\end{tabular}

\# - Values expressed as the mean \pm SD of six replicates.

${ }^{\mathrm{a}}$ and ${ }^{\mathrm{b}}-$ Values were significantly different $(\mathrm{p}<0.001$ and $\mathrm{p}<0.01$ respectively) from the control when the $\mathrm{t}$ test was applied.

$\mathrm{a}^{\prime}, \mathrm{b}^{\prime}$ and $\mathrm{c}^{\mathrm{c}^{\prime}}-$ Values were significantly different $(\mathrm{p}<0.001, \mathrm{p}<0.01$ and $<0.05$ respectively) within the various concentrations when the t-test was applied.

\section{Effect of methoprene on insect developmental time (growth duration)}

Table 5 shows that there were significant differences in the duration of development between control and treatments. The growth duration of $1^{\text {st }}$ instar larvae treated with methoprene at concentrations of $2,4,8$ and $12 \mathrm{ppm}$ was $64.83 \pm 4.05,66.70 \pm 2.74,71.50 \pm$ 4.23 and $72.50 \pm 3.39$ days for males and $71.00 \pm 4.05,75.83 \pm 2.32,76.67 \pm 2.16$ and $82.00 \pm 2.37$ days for females respectively. The duration was longest at higher concentrations. Similar results were obtained when $2^{\text {nd }}, 3^{\text {rd }}$ and $4^{\text {th }}$ instars larvae were treated with methoprene. This result showed that the developmental time of larvae treated with high concentrations of methoprene ( 8 and $12 \mathrm{ppm})$ was delayed slightly. The growth duration of $1^{\text {st }}$ instar larvae treated with $12 \mathrm{ppm}$ was $72.50 \pm 3.39$ days for males and 82.00 \pm 2.37 days for females, that is, much longer than the control, i.e. $42.33 \pm 3.27$ days (males) and $45.00 \pm 2.37$ days (females). 

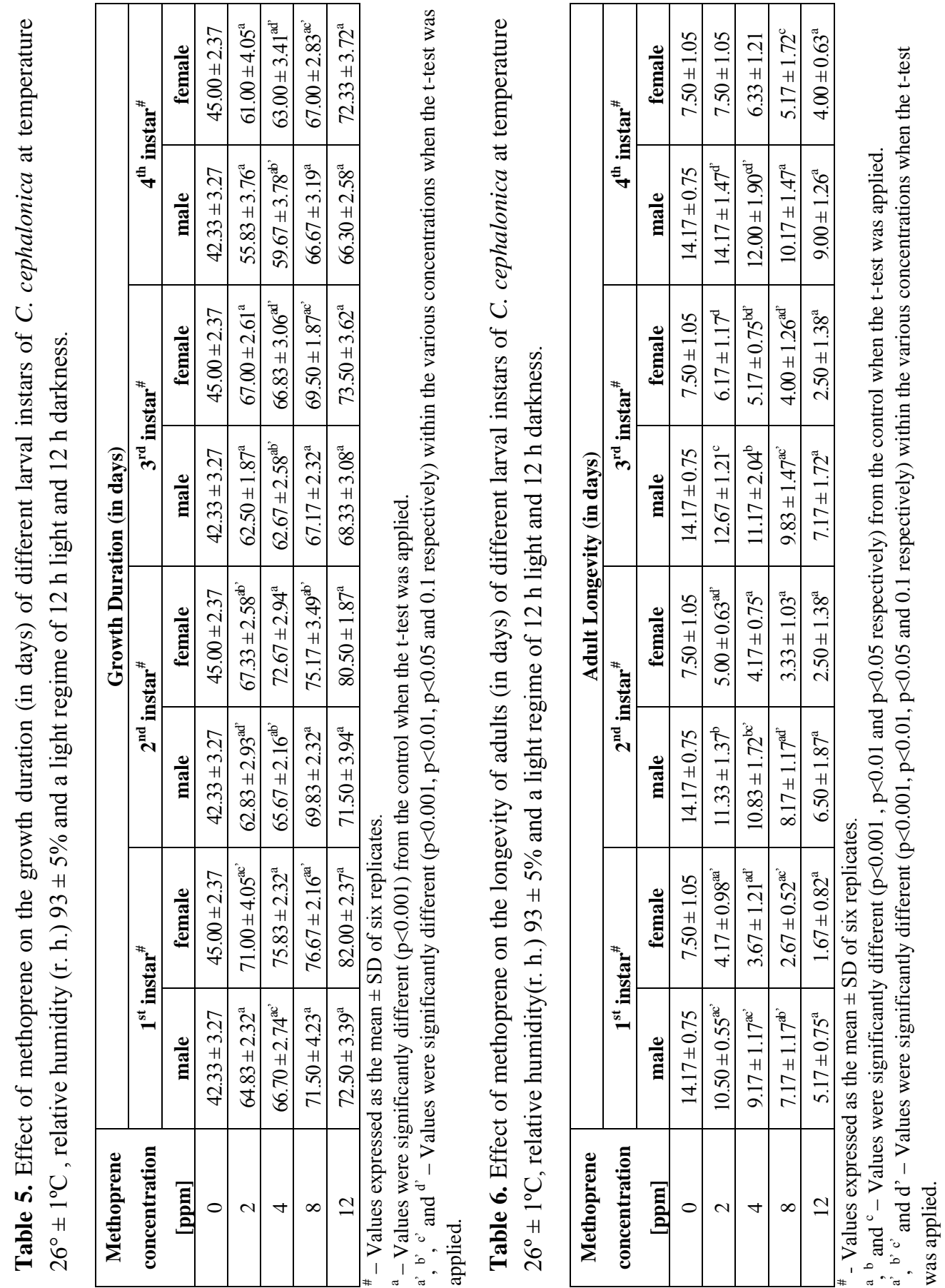


\section{Effect of methoprene on longevity}

When $1^{\text {st }}$ instar larvae were treated with methoprene, the longevity of adults (both males and females) was significantly different among the four concentrations used. Similar results were obtained when larvae of other instars $\left(2^{\text {nd }}, 3^{\text {rd }}\right.$ and $\left.4^{\text {th }}\right)$ were treated (Table 6). The survival rate of adults (both males and females) was significantly lower when the larvae were treated with the highest concentration of methoprene (12 ppm). Adult longevity observed in the control was $14.17 \pm 0.75$ days in males and $7.5 \pm 1.05$ days in females, while longevity at the highest concentration $(12 \mathrm{ppm})$ in $1^{\text {st }}, 2^{\text {nd }}, 3^{\text {rd }}$ and $4^{\text {th }}$ instars was 5.17 $\pm 0.75,6.50 \pm 1.87,7.17 \pm 1.72$ and $9.00 \pm 1.26$ days in males and $1.67 \pm 0.82,2.50 \pm 1.38$, $2.50 \pm 1.38$ and $4.00 \pm 0.63$ days in females respectively (Table 6).There was no difference in the longevity of adult females in $2^{\text {nd }}$ and $3^{\text {rd }}$ instar larvae when treated with $12 \mathrm{ppm}$ of methoprene. In the case of $4^{\text {th }}$ instar larvae treated with $2 \mathrm{ppm}$ of methoprene, the longevity of both males and females was $14.17 \pm 1.47$ days and $7.50 \pm 1.05$ days respectively, which was similar to the control (Table 6).

\section{DISCUSSION}

In the present investigation, methoprene, a juvenile hormone analogue applied to different larval instars of the rice moth Corcyra cephalonica resulted in increased larval mortality, pupal mortality and growth duration on the one hand, and decreased pupation, adult emergence and longevity on the other. By virtue of their different modes of action, juvenoids and CSIs affect larval growth in quite opposite ways. JHAs at the mature larval stage induce juvenilization of the treated larva when the natural hormone is absent in the body. Hence, these compounds inhibit pupation of the treated larvae, which continue to moult and produce "giant" or "supernumerary larvae", as reported in Tribolium beetles (PALLOS et al. 1971, ISHAAYA \& YABLONSKI 1976, RAO 1977, El-SAYED 1987, SHAAYA \& PISAREV 1988, SMET et al. 1989), Plodia interpunctella HÜBNER, 1816 (KRAMER \& MCGREGOR 1979) and in Ephestia cautella WALKER, 1863 (SHRIVASTAVA 1983, SHAAYA \& PISAREV 1986, 1988). Concentrations from 1 to $100 \mathrm{ppm}$ of different JHs have been reported to produce such giant larvae in Tribolium beetles. IGRs may disturb larval growth by affecting larval weight and length, increasing the larval period and causing larval mortality at different instars resulting in a reduced percentage of pupal eclosion. Larval survival is lower in external feeders than in internal feeders developing on an IGR-treated diet (LOSCHIAVO 1975, MiAN \& MULla 1982). Insufficient penetration of the active ingredient into the endosperm of the kernels is the reason why IGRs fail to induce mortality in weevils at economic concentrations. Rates of penetration also differ in different grains: for example, $10 \mathrm{ppm}$ methoprene or other JHAs in wheat caused mortality in flour beetles, 
whereas $1 \mathrm{ppm}$ of methoprene in oats was lethal to the larvae of grain beetles (LOSCHIAVO 1975, 1976). Larvae of different stored-product insects treated with BPUs have been found to shrink: the body wall becomes loose, and they cease normal movement, gradually turning black and ultimately dying (MIAN \& MULLA 1982, VIR 1988, PARWEEN 1998). In the present investigation larval mortality was strongly affected by methoprene: for example, larval mortality in the control was $3.33 \pm 3.01 \%$ whereas in $1^{\text {st }}$ instar larvae treated at the highest concentration of $12 \mathrm{ppm}$, larval mortality was $26.67 \pm 3.26 \%$.

The highest concentration, i.e. $12 \mathrm{ppm}$ of methoprene, when applied to $1^{\text {st }}, 2^{\text {nd }}, 3^{\text {rd }}$ and $4^{\text {th }}$ instar larvae, led to an age-dependent reduction in pupation. That is to say, $1^{\text {st }}$ instar larvae exposed to $12 \mathrm{ppm}$ of methoprene exhibited maximum reduction in pupation, whereas in $4^{\text {th }}$ instar larvae exposed to the same concentration of methoprene showed minimum reduction in pupation (Table 2). When $1^{\text {st }}, 2^{\text {nd }}, 3^{\text {rd }}$ and $4^{\text {th }}$ instar larvae were treated with $12 \mathrm{ppm}$ methoprene their pupation were reduced by $73.33 \pm 3.27,74.67 \pm 2.07$, $78.00 \pm 2.19$ and $80.67 \pm 3.01 \%$ respectively in comparison to the untreated control (96.67 $\pm 3.01 \%)$. Similar findings were also reported in case of $4^{\text {th }}$ and $5^{\text {th }}$ instar larvae of Corcyra cephalonica when exposed to JHA Ro 20-3600. Their pupation fell to 70\% in comparison with the control (BHARGAVA \& DEVRAJ URS 1992). The reduction in pupation could be due to ecdysis failure, caused in turn by the inhibition of the secretion or activity of moulting hormone (SLÁMA et al. 1974). Most JHAs at a concentration of $10 \mathrm{ppm}$ or above inhibit pupal eclosion in both beetles and moths of stored grain (CARTER 1975, FAJARDO \& MORALLO-REJESUS 1980, MiAN \& MULLA 1982).

IGRs often result in pupal mortality either by direct treatment, as reported by SOLTANI et al. (1993), or by larval treatment. The formation of a pupal-adult intermediate in Tenebrio molitor LINNAEUS, 1758 larvae when treated with IGRs results in increased pupal mortality in this insect (EDWARDS 1976, PARWEEN 1996). Pupal mortality is dosedependent (PARWEEN 1996) and decreased with increased pupal age (SOLTANI et al. 1993, EDWARDS 1976). The present work has shown that the percentage pupal mortality was higher in younger instars $\left(1^{\text {st }}\right.$ and $\left.2^{\text {nd }}\right)$ of Corcyra cephalonica when treated with methoprene: it was $29.10 \pm 2.88 \%$ in the case of $1^{\text {st }}$ instar larvae when treated with $12 \mathrm{ppm}$ of methoprene. This is comparable with the result reported by MIAN \& MULLA (1982), i.e. when larvae treated with $5 \mathrm{ppm}$ of methoprene resulted in 65 and $83 \%$ pupal mortality in $1^{\text {st }}$ and $2^{\text {nd }}$ instar larvae of Rhyzopertha dominica FABRICIUS, 1792 respectively and 60 and $100 \%$ in $1^{\text {st }}$ and $2^{\text {nd }}$ instars of Tribolium castaneum HERBST, 1797 respectively.

WILLIAMS (1956) was the first to report that JH application to young pupae blocked adult differentiation. The activity of IGRs against the developmental stages certainly results in reduced adult emergence. JH treatment at any stage reduces adult emergence in storedproduct insects (PALlos et al. 1971, LOSCHIAVO 1975, 1976, NORDLANDER 1975, OBERLANDER \& SilHaCeK 1976, AMOS \& Williams1977, KRAMER \& MCGREgOR 1979, 
StOCKel \& EdWARds 1981, IshaAya 1982, Mian \& Mulla 1982, Benezet 1983, RuP \& CHOPRA 1984, ABO-EL-GHER 1992). Methoprene effectively inhibited adult emergence in Sitotroga cerealella OLIVIER, 1789 (STOCKEL \& EDWARDS 1981) and Alphitobius diaperinus PANZER, 1797 (EDWARDS \& ABRAHAM 1985). Longer exposure of eggs or larvae to low concentration of BPUs resulted in 90-100\% inhibition of adult emergence in Trogoderma granarium EVERTS, 1898 (SAXENA \& KUMAR 1982, 1991, VIR 1988), Tribolium castaneum (ISHAAYA et al. 1981, SAXENA \& MATHUR 1981, MiAN \& MULLA 1982, EISA et al. 1984, 1986, ADAN et al. 1992, Del EstAL et al. 1990, MondAL et al. 1999), Tribolium confusum JACQUELIN DU VAL, 1863 (EL-SAYED et al. 1984), Ephestia cautella (WALKER, 1863) and Lasioderma serricorne (FABRICIUS, 1792) (MENN et al. 1981). In the present investigation the adult emergence was $96.67 \pm 3.01 \%$ in the control, and $52.00 \pm 3.58$ and $70.67 \pm 4.13 \%$ in $1^{\text {st }}$ and $4^{\text {th }}$ instar larvae respectively following treatment with $12 \mathrm{ppm}$ of methoprene. These findings revealed that longer exposure of Corcyra cephalonica larvae to methoprene has a greater effect on the rate of adult emergence. Our findings are in accordance with the results of MOJAVER \& BADNANI (2010) obtained in the case of Eurygaster integriceps PUTON, 1881 exposed to pyriproxyfen.

IGRs as a whole disrupt insect metamorphosis, hence, the developmental time for pupation and adult eclosion are much longer. Short exposure of particular instars of insect larvae to IGRs did not affect the developmental time, but long exposure usually showed profound effects (MIAN \& MULLA 1982). In the present investigation the application of methoprene to different larval stages of the rice moth had a significant effect on their developmental time. There was a slight increase in developmental time (growth duration) when younger instars were treated with the highest concentration (12 ppm) of methoprene. The growth duration of rice moth in the control was $42.33 \pm 3.27$ days for males and 45.00 \pm 2.37 days for females, whereas in $1^{\text {st }}$ instar larvae treated with $12 \mathrm{ppm}$ it was $72.50 \pm 3.39$ days for males and $82.00 \pm 2.37$ days for females. The longest developmental time (growth duration) was obtained when $1^{\text {st }}$ instar larvae were treated. This result was comparable to that obtained for the effect of pyriproxifen on Plodia interpunctella (GHASEMI et al. 2010) and on Eurygaster integriceps (MOJAVER \& BADNANI 2010). In contrast to this result, the application of fenoxycarb to $2^{\text {nd }}$ to $4^{\text {th }}$ larval instars of the European corn borer Ostrinia nubilalis (HÜBNER, 1796) had no significant effects on the duration of these instars and the duration of the resulting $5^{\text {th }}$ instars increased significantly (GADENNE et al. 1990).

In the present work, the longevity of Corcyra cephalonica adults emerging from methoprene-treated larvae was significantly reduced in comparison to the control. In the control, adult longevity was $14.17 \pm 0.75$ days for males and $7.50 \pm 1.05$ days for females, whereas the adult longevity of emerged adults from $1^{\text {st }}$ and $4^{\text {th }}$ instars treated with $12 \mathrm{ppm}$ of methoprene was $5.17 \pm 0.75$ days and $9.00 \pm 1.26$ days for males, and $1.67 \pm 0.82$ days and $4.00 \pm 0.63$ days for females respectively. This shows that the early larval stage was 
more affected by methoprene than the older one ( $4^{\text {th }}$ instar). Similar findings were reported following the action of pyriproxyfen on Eurygaster integriceps (MOJAVER \& BADNANI 2010). This finding was also similar to that of Plodia interpunctella exposed to $0.3 \mathrm{ppm}$ of pyriproxyfen (GHASEMI et al. 2010). However, the juvenile hormone analogue methoprene and pyriproxyfen have very different effects on the life spans of the three species. They have no effect on the life span of Rhyzopertha dominica (FABRICIUS, 1792) and Sitophilus oryzae (LINNAEUS, 1763), but have a profound effect on Tribolium castaneum (KOSTYUKOVSKY et al. 2000). Most IGRs are generally not toxic to the adults themselves, but long exposure to the early larval stages causes disruptions in the organ systems or interrupts adult ecdysis and reduces the adult life span in the treated insects (MONDAL \& PARWEEN 2001).

A number of JHAs, including methoprene, at concentrations from 0.10 to100 ppm produced adultoids with crumpled and greatly diverging wings and supernumerary larvae in Tribolium confusum (SMET et al. 1989). Normal adults that emerged from these treatments produced some small sized adults in the F1 generation in the treated diet, which moved slowly compared to the untreated F1 adults. In the present investigation, increasing the concentrations resulted in a low emergence of normal adults, and some adultoids emerged from the treated larvae (more pronounced at $12 \mathrm{ppm}$ concentration). These adultoids exhibited abnormal legs and twisted wings; movement of the legs and wings was thus impossible (Figs A, B1, B2). Increasing the concentration of methoprene also resulted in the formation of abnormal pupae, i.e. pupoids (Figs C, D1, D2, D3). Adults of Sitophilus oryzae emerging from methoprene-treated larvae had crooked snouts and collapsed abdomens (BAKER \& LUM 1976). Methoprene, hydroprene and MV-678 produced deformed adults in Ephestia cautella in treated shell peanuts (NICKLE 1979). The carbamate group of JHAs produced giant larvae with large head capsules in Tribolium castaneum and adultoids in Sitophilus granarius (HOPPE 1976). Carbamates affected the lepidopteran species Ephestia kuehniella ZELLER, 1879 and Plodia interpunctella more than Tribolium beetles. Adult moths with deformed wings and strongly bent abdomens were incapable of flight (HOPPE 1974, 1976). Minimal metamorphic defects, for example, uninflated and crumpled wings and disturbed ecdysis in JH-treated Sitophilus granarius was reported by STAAL (1975). Hydroprene and R-20458 at concentrations of 20, 50 and $100 \mathrm{ppm}$ produced severe deformities in females of Sitophilus oryzae in the form of larval-pupal, larval-adult and pupal-adult intermediates (MKHIZE 1986). Besides the intermediate forms, incomplete moults also occurred, for example, a larval head capsule found on the abdomen of an otherwise normal pupa, a pupal exuvium adhering either to the legs or the tip of ventral side of the abdomen of an apparently normal adult beetle, deformed elytra and hind wings and uneven pigmentation. The degree of completion of metamorphosis was dose-dependent. 

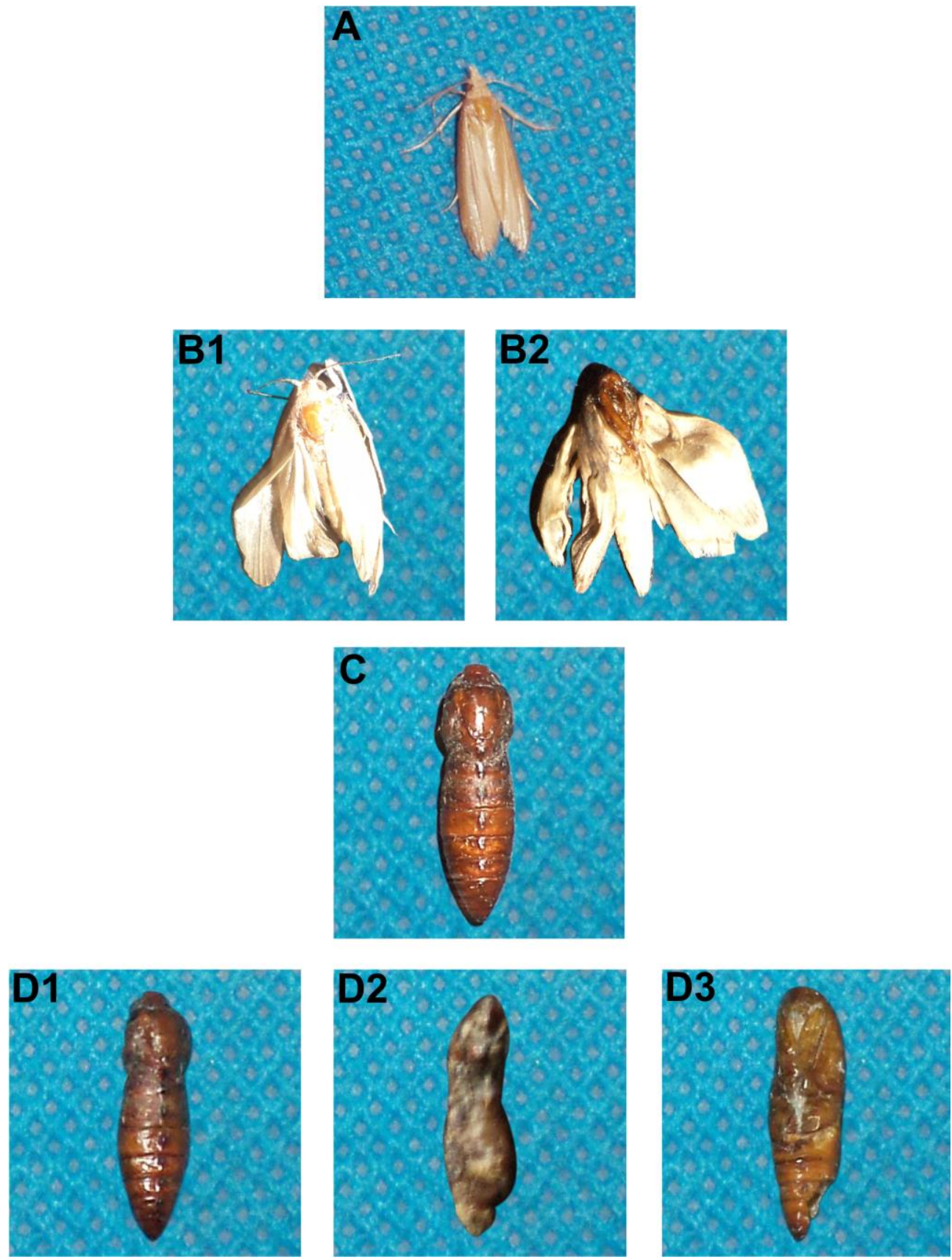

Fig. 1. Corcyra cephalonica: A - a normal adult; B1, B2 - abnormal adults with twisted wings and abnormal legs; C - normal pupa; D1, D2, D3 - abnormal pupae (pupoids). 
These deformities were more pronounced in the females than the males, which may be due to the shorter pupal period and earlier differentiation of adult tissues in the male beetles. Diapausing larvae of Trogoderma granarium treated with $1 \mu \mathrm{g} / \mathrm{larva}$ of this JH were able to initiate pupation and adult emergence occurred. These adults showed normal features except that their legs were poorly developed and did not show any sign of tanning. Methoprene at doses of 10 and $100 \mu \mathrm{g} / \mathrm{pupa}$ and hydroprene at $10 \mu \mathrm{g} / \mathrm{pupa}$ on Sitotroga cerealella produced deformed adults, the males being more affected than the females (STOCKEL \& EDWARDS 1981). Both JHAs and CSIs produced larval-pupal intermediates and abnormal adults in Plodia interpunctella and Corcyra cephalonica (FAJARDO \& MORALLO-REJESUS 1980). From our findings it should be concluded that methoprene reduces the percentages of pupation, adult emergence and adult longevity, and may prolong the developmental time (growth duration). It should be clear that methoprene may be considered a safer substitute for conventional insecticides and may be utilized for the effective control of Corcyra cephalonica in particular and lepidopteran pests in general.

\section{REFERENCES}

AвO EL-GHER G.E.S. 1992. Effect of insect growth regulators with juvenile hormone activity against Callosobruchus maculatus (F.) (Coleoptera: Bruchidae). Anzeiger für Schädlingskunde, Pflanzenschutz, Umweltschutz 65(7): 137-140.

Adan A., Del Estal P., Budia F., Narco V., Jacas J., Vinuela E. 1992. Effects of hexaflumuron on the fecundity and fertility of Tribolium castaneum HERBST (Coleoptera: Tenebrionidae). Boletin de Sanidad Vegetal - Plagas 20(2): 371-377.

Allotey J. 1991. Development and fecundity of the rice-moth, Corcyra cephalonica (Pyralidae). Discovery and Innovation 3(4): 123-126.

Allotey J., Kumar F. 1985. Competition between Corcyra cephalonica (STAINTON) and Ephestia cautella (WALKER) in cocoa beans. Insect Science and its Application 6(5): 627-632.

Amos T.G., WiLLiams P.1977. Insect growth regulators: some effects of methoprene and hydroprene on productivity of several stored grain insects. Australian Journal of Zoology 25(2): 201-206.

Atwal A.S. 1976. Agricultural pests of India and South East Asia. Kalyani Publishers, Delhi.

AYYAR T.V.R. 1920. Some insects recently noticed as injurious in South India. [in:] T. BAINBRIDGE Fletcher (ed.). Report of the Proceeding of the Third Entomology Meeting Held at Pusa, $3^{\text {rd }}$ to $15^{\text {th }}$ February 1919. Volume 1. Superintendent Government Printing, Calcutta: 314-328.

BAKER J.E., LUM P.T. 1976. Effects of dietary methoprene on symbiotic and aposymbiotic rice weevils and asymbiotic granary weevils. Journal of Georgia Entomological Society 11(3): 213 216.

BENEZET H.J. 1983. Survival of the consecutive generations of cigarette beetle reared in media containing less than $1.0 \mathrm{ppm}$ methoprene. [in:] J.H. BocZEK (ed.). Proceedings of the Third International Working Conference on Stored-Product Entomology: October 23-28, 1983, Kansas State University, Manhattan, Kansas: 217-221.

Bengston M. 1987. Insect growth regulators. [in:] E. Donahaye, S. NAVARro (eds.). Proceedings of the fourth International Working Conference on Stored-Product Protection, 21-26 September 
1986, Tel Aviv, Israel. Maor-Wallach Press, Jerusalem, Israel: 35-46.

Bhargava M.C., Devraj UrS K.C. 1992. Activity of juvenile hormone analogue (RO 20-3600) on larvae of Corcyra cephalonica STAINTON (Lepidoptera: Pyralidae). Bulletin of the Grain Technology 30(2): 119-124.

Burkholder W.E., FAuStini D.L. 1991. Biological methods of survey and control. [in:] J.R. GORHAM (ed.). Ecology and Management of Food Industry Pests. Association of Official Analytical Chemists, Arlington, Virginia: 361-372.

CARTER S.W. 1975. Laboratory evaluation of three novel insecticides inhibiting cuticle formation against some susceptible and resistant stored products beetles. Journal of Stored Product Research 11(3-4): 187-193.

Del Estal P.D., Vinuela E., Adan A., Budia F. 1990. Effects of the insect growth regulator XRD473 (Hexaflumuron) on Tribolium castaneum HeRBST (Coleoptera: Tenebrionidae). Boletin de Sanidad Vegetal - Plagas 16(1): 339-345.

EDWARDS J.P. 1976. Age-related susceptibility of Tribolium castaneum (HERBST) to synthetic $\mathrm{C}_{18}$ Juvenile hormone. Journal of Stored Product Research 12(2): 71-76.

EDWARDS J.P., MENN J.J. 1981. The use of juvenoids in insect pest management. [in:] R. WeGLER (ed.). Insecticides - Bactericides - Oomycete Fungicides. Biochemical and Biological Methods Natural Products. Springer-Verlag, Berlin - Heidelberg: 185-214.

EDWARDS J.P., ABRAHAM L. 1985. Laboratory evaluation of two insect juvenile hormone analogues against Alphitobius diaperinus (PANZER) (Coleoptera: Tenebrionidae). Journal of Stored Product Research 21(4): 189-194.

EISA A.A., AMmAR I.M.A., El-SHEIKH A.E.A. 1986. Effect of the two insect growth regulators and the ovicide isoxathion on the red flour beetle, Tribolium castaneum HERBST when admixed with wheat flour as egg treatment. Annals of Agricultural Science 24(3): 1689-1696.

EISA A.A., Ammar I.M.A., RADWAN H.S.A., El-NABAwI A. 1984. Larvicidal activity and development inhibition of the red flour beetle, Tribolium castaneum HERBST, fed on insect growth regulators treated wheat flour. Minufiya Journal of Agriculture Research 8: 405-414.

EL-SAYED F.M.A. 1987. Effect of the synthetic insect growth regulator methoprene on larval development and reproduction of two species of stored product insects. Bulletin de la Société Entomologique d'Egypte 65: 215-221.

EL-SAYED F.M.A., RAZIK M.A., KANDIL M.A.1984. Biological activity of the insect growth regulator triflumuron against Tribolium confusum (Duv.). Bulletin of the Entomological Society of Egypt, Economic series 14: 171-176.

FAJARdo V., Morallo-Rejesus B. 1980. Effect of ten insect growth regulators on Plodia interpunctella HBN. and Corcyra cephalonica STAINT. Philippine Entomology 4(3): 169-175.

Gadenne C., Grenier S., Plantevin G., Mauchamp B. 1990. Effects of a juvenile hormone mimetic, fenoxycarb, on postembryonic development of the European corn borer, Ostrinia nubilalis HBN. Experientia 46(7): 744-747.

Ghasemi A., Sendi J.J., Ghadamyari M. 2010. Physiological and biological effect of Pyriproxifen on the Indian meal moth Plodia interpunctella (HÜBNER) (Lepidoptera: Pyralidae). Journal of Plant Protection and Research 50(4): 416-422.

HenRick C.A., StaAl G.B., SidDall J.B. 1973. Alkyl 3, 7, 11-trimethyl-2, 4-dodecadi-enoates, a new 
class of potent insect growth regulators with juvenile hormone activity. Journal of Agriculture and Food Chemistry 21(2): 354-359.

HILL S.D. 1990. Pests of Stored Products and their Control. Belhaven Press, London.

HopPE T. 1974. Effects of a juvenile hormone analogue on Mediterranean flour moth in stored grains. Journal of Economic Entomology 67(6): 703-716.

HOPPE T. 1976. Micro plot trial with an epoxyphenylether (insect growth regulator) against several pests of stored wheat grain. Journal of Stored Product Research 12(3): 205-209.

ISHAAYA I. 1982. Biological and biochemical aspects of the disruption of adult formation in Tribolium by a novel bis(thiocarbamate) R-31026 and the juvenoid R-20458. Pesticide Science 13(2): 204-210.

ISHAAYA I., ASCHER K.R.S., YABLONSKI S.1981. The effect of BAY SIR 8514, diflubenzuron and Hercules 24018 on growth and development of Tribolium confusum. Phytoparasitica 9(3): 207-209.

ISHAAYA I., YABLONSKI S.1976. Induction of prolonged larval feeding stage by hormone analogues in Tribolium castaneum. Phytoparasitica 4(1): 9-18.

Khan A.R., Mannan A. 1991. Stored-products entomology in the tropics. [in:] K. Evans (ed.). Agricultural Zoology Reviews, vol. 4. Intercept, Andover: 67-95.

Kostyukovsky M., Chen B., Atsmi V., ShaAya E. 2000. Biological activity of two juvenoids and two ecdysteroids against three stored product insects. Insect Biochemistry and Molecular Biology 30(8-9): 891-897.

KRAMER K.J., McGRegor H.E. 1979. Activity of seven chitin synthesis inhibitors against development of stored product insects. Environmental Entomology 8(2): 274-276.

LADISCH P.K., LADISCH S.K., Howe P.M. 1967. Quinoid secretion in grain and flour beetles. Nature 215(5104): 939-940.

Loschiavo S.R. 1975. Tests of four synthetic growth regulators with juvenile hormone activity against seven species of stored products insects. The Manitoba Entomologist 9: 43-52.

Loschiavo S.R. 1976. Effect of the Synthetic Insect Growth Regulators Methoprene and Hydroprene on Survival, Development or Reproduction of Six Species of Stored Products Insects. Journal of Economic Entomology 69(3): 395-399.

MARX J.L. 1977. Chitin synthesis inhibitors, new class of insecticides. Science 197(4309): 170-172.

Menn J.J., Henrick C.A., StaAl G.B. 1981. Juvenoids: bioactivity and prospects for insect management. [in:] M. KLOZA (ed.). Regulation for Insect Development and Behaviour. Wrocław Technical University Press, Wrocław: 735-748.

Mian L.S., MulLa M.S. 1982. Biological activity of IGRs against four stored product coleopterans. Journal of Economic Entomology 75(1) 80-85.

MKHIZE J.N. 1986. Activity of insect growth regulators with juvenile hormone-like effects against the rice weevil Sitophilus oryzae (L.) (Coleoptera:Curculionidae). Tropical Pest Management 32(4): 324-326. 
MojaVER M., BANDANi A.R. 2010. Effects of the insect growth regulator pyriproxyfen on immature stages of Sunn Pest, Eurygaster integriceps PUTON (Heteroptera: Scutelleridae). Munis Entomology and Zoology 5(1): 187-197.

MonDAL K.A.M.S.H. 1983. Response of Tribolium castaneum larvae (HERBST) to the different components of conditioned medium. Tribolium Information Bulletin 23: 104-111.

Mondal K.A.M.S.H. 1984. Effects of Methylquinone, Aggregation Pheromone and Pirimiphosmethyl on Tribolium castaneum HERBST larvae. Ph.D. thesis, University of Newcastle upon Tyne, UK.

MonDAL K.A.M.S.H. 1985. Response of Tribolium castaneum larvae to aggregation pheromone and quinones produced by adult conspecifics. Integrated Pest Control 27(3): 64-66.

MondaL K.A.M.S.H. 1992. Quinone secretions of the flour beetles, Tribolium: Problems and Prospects. Tribolium Information Bulletin 32: 79-89.

MondaL K.A.M.S.H. 1994. Flour beetles Tribolium spp. (Coleoptera: Tenebrionidae) as pests and their control. [in:] K. Evans (ed.). Agricultural Zoology Reviews, vol. 6. Intercept, Andover: 95-119.

Mondal K.A.M.S.H., PARweEN S. 2001. Insect growth regulators and their potential in the management of stored-product insect pests. Integrated Pest Management Reviews 5(4): 255-295.

Mondal K.A.M.S.H., Parween S., Reichmuth C., Akhtar N. 1999. Effect of triflumuron on the development of the red flour beetle, Tribolium castaneum (HERBST) (Coleoptera: Tenebrionidae). [in:] Z. Jin, Q. LiAnG, Y. LIANG, X. TAN, L. GuAN (eds.). Proceedings of the $7^{\text {th }}$ International Working Conference on Stored-product Protection, 14-19 October 1998, Beijing, China. Volume 1. Sichuan Publishing House of Science \& Technology, Chengdu, China: 14-17.

MunRo J.W., Thomson W.S. 1929. Report on insect infestation of stored cocoa. H.M. Stationery Office, London.

NICKLE D.A. 1979. Insect growth regulators: New protectants against the almond moth in stored in shell peanuts. Journal of Economic Entomology 72(6): 816-819.

NORDLANDER G. 1975. Tests with Altozar and Altosid against two insect pests of stored grain. Vaxskyddsnotiser 39(6): 136-139.

OBERLANDER H., SilhaCeK D.L. 1976. Action of juvenile hormone on marginal discs of the Indian meal moth. [in:] L.I. GILBERT (ed.). The Juvenile Hormones. Plenum Press, New York: 220-233.

Oberlander H., Silhacek DL., ShaAya E., IshaAya I. 1997. Current status and future perspectives of the use of insect growth regulators or the control of stored product insects. Journal of Stored Product Research 33(1):1-6.

Pallos F.M., Menn J.J., Letchworth P.E., Miaullis J.B. 1971. Synthetic mimics of insect juvenile hormone. Nature 232(486): 486-487.

PARWEEN S. 1996. The effect of Triflumuron on malathion susceptible (FSS II) and malathion resistant (CTC 12) strains of Tribolium castaneum HERBST. Ph.D. Thesis, University of Newcastle upon Tyne, UK.

PARWEEN S. 1998. Symptoms of Triflumuron intoxication in larvae of Tribolium castaneum (HERBST) (Coleoptera: Tenebrionidae). Tribolium Information Bulletin 38: 268-270. 
Piltz H.1977. Corcyra cephalonica (Staint). [in:] J. KranZ, H. Schmutterer, W. Koch (eds.). Diseases pests and weeds in tropical crops. Verlag Paul Parey, Berlin and Hamburg: 439-440.

RAO R.P. 1977. Effect of 'Enstar', a juvenile hormone analogue on the larvae and pupae of the red flour beetle Tribolium castaneum (HERBST). Journal of Food Science and Technology 14(3): 132-133.

REYNOLDS S.E. 1987. The cuticle, growth and moulting in insects: The essential background to the action of acylurea insecticides. Journal of Pest Science 20(2): 131-146.

Rотн L.M. 1943. Studies on the gaseous secretion of Tribolium confusum DuVAL II. The odoriferous glands of Tribolium confusum. Annals of Entomological Society of America 36(3): 397-424.

RuP P.J., ChopRa P.K. 1984. Effect of hydroprene on Callosobruchus maculatus (F.) (Coleoptera: Bruchidae). Journal of Stored Product Research 20(4): 229-232.

SAXENA S.C., KumAR D. 1991. Effects of two new chitin synthesis inhibitor compounds on different developmental stages of Trogoderma granarium (Evert). Journal of Animal Morphology and Physiology 38(1-2): 99-108.

SAXENa S.C., Kumar V. 1982. Effect of two chitin inhibitors on reproduction of Trogoderma granarium. Entomon 7(2): 141-144.

SAXENA S.C., MATHUR G. 1981. Suppression of adult emergence by administering new synthesized chitin synthesis inhibitor compound in Tribolium castaneum HERBST. Journal of Environmental Biology 2(1): 7-10.

ShaAya E., PisAREV V. 1986. The lethal effects of three insect juvenile hormone analogues on the developmental stages of Ephestia cautella (WALK.) (Lepidoptera: Phycitidae). Journal of Stored Product Research 22(3): 125-129.

ShaAya E., PISAREV V. 1988. The effect of S-31183, an insect growth regulator on the development of Ephestia cautella and Tribolium castaneum. [in:] Progress Report, Stored Products Division, Agricultural Research Division, Agricultural Research Organization, Israel, 1985/87: 19-27.

SHRIVASTAVA R.C. 1983. Effect of treatment of larvae with a juvenoid on the fecundity of certain stored grain insects. Industrial Zoology 7(1-2): 75-80.

SlÁmA K., RomañUK M., ŠoRM F. 1974. Insect Hormones and Bioanalogues. Springer-Verlag, Berlin.

Smet H., Rans M., De Loof A. 1989. Activity of new juvenile hormone analogues on a stored food insect, Tribolium confusum (J. DU VAL) (Coleoptera: Tenebrionidae). Journal of Stored Product Research 25(3): 165-170.

Soltani N., Chebira S., Delbecque J.P., Delachambre J. 1993. Biological activity of flucycloxuron, a novel benzoylphenylurea derivative on Tenebrio molitor: Comparison with diflubenzuron and triflumuron. Experientia 49(12): 1088-1091.

STAAL G.B. 1975. Insect growth regulators with juvenile hormone activity. Annual Review of Entomology 20: 417-460.

STOCKel J., EdWARdS J.P. 1981. Susceptibility of Sitotroga cerealella (OlIV.) (Lepidoptera: Gelechiidae) to two insect juvenile hormone analogues. Journal of Stored Product Research 17(3): 137-141. 
Thomas P.J., BhatnagaR-Thomas P.L. 1968. Use of a juvenile hormone analogue as insecticide for pests of stored grain. Nature 219(5157): 949.

VIR S. 1988. Effect of diflubenzuron-a chitin synthesis inhibitor on Khapra beetle, Trogoderma granarium EVERTS. (Coleoptera: Tenebrionidae). Bulletin of Grain Technology 26(2): 126-129.

Wilbur D.A., Mills R.B. 1985. Stored Grain Insects. [in:] R.E. Pfadt (ed.). Fundamentals of Applied Entomology, $4^{\text {th }}$ edition. MacMillan Publishing Co., New York: 552-576.

WiLLIAMS C.M. 1956. The juvenile hormone of insects. Nature 178(212): 212-213.

WILLIAMS C.M. 1967. Third generation pesticides. Scientific American 217: 13-17.

WiLLIS J.H. 1974. Morphogenetic action of insect hormones. Annual Review of Entomology 19: 97-115.

WING H.D., ALLER H.E. 1990. Ecdysteroid agonists as novel insect growth regulators. [in:] E. CASIDA (ed.). Pesticides and Alternatives: Innovative Chemical and Biological Approaches to Pest Control. Elsevier Scientific Publishers B.V., Amsterdam: 251-257.

WMO [World Meteorological Organization] 1994. Scientific assessment of ozone depletion. Executive summary. World Meteorological Organization Global Ozone Research and Monitoring Project - Report No. 37. World Meteorological Organization, Geneva.

Received: 10 September 2013

Accepted: 13 January 2014 